\title{
The Early Exploitation of Southeast Asian Mangroves: Bone Technology from Caves and Open Sites
}

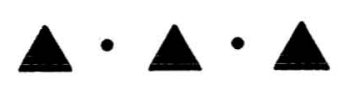

\author{
RYAN J. RABETT
}

\begin{abstract}
DEBATES AROUND THE CLASSIFICATION AND SIGNIFICANCE of lithic technology have been a prime focus of more than a century of archaeological investigation in Southeast Asia. Topics ranging from cultural evolution to cultural affiliation and adaptation to rainforest conditions have all stemmed from their analysis. By contrast, bone technology has received much less attention, a somewhat surprising fact given the cultural and behavioral importance ascribed to the appearance of this technology in the prehistoric record elsewhere in the world, particularly in Europe. In many published site reports ${ }^{1}$ from Southeast Asia, discussions about bone technology come at the end of descriptions of material culture or even appear as part of faunal analysis. To date, systematic efforts to compare and categorize inventories from more than one site remain scarce (e.g., Harrisson and Medway 1962; Higham 1993; Olsen and Glover 2004). The material discussed in this paper comes from a multisite study of prehistoric bone technology (Rabett 2002).
\end{abstract}

\section{BONE TECHNOLOGY IN SOUTHEAST ASIA IN THE LATE PLEISTOCENE TO MID HOLOCENE ${ }^{2}$}

Osseous implements have been found across Southeast Asia in some late Pleistocene contexts, for example, associated with deep deposits at Niah Cave, Sarawak, recently confirmed to date from ca. 40,000 B.P. ${ }^{3}$ (Barker et al. 2001); from deposits dating to before the Last Glacial Maximum at Lang Rongrien (Anderson 1988); and from Hagop Bilo cave in Sabah, broadly dated to 17,000-12,000 B.P. (Bellwood 1988). However, it is not until the period between the terminal Pleistocene and mid Holocene (approximately 11,000-4000 B.P.) that bone-based technologies appear to become more widespread in the region.

In east Java, the first prehistoric bone tool industry to be reported in the region was the "Sampung," after the site of the same name near the town of Ponorogo

Ryan J. Rabett, Department of Archaeology, University of Cambridge. 
(Van Es 1929). At this and other related sites, perhaps most notably Gua Lawa (Hoekgrot), a large number of implements was recovered, often from apparently preceramic levels (Erdbrink 1954). These ranged from fishhooks to worked antler and horn and two kinds of "spatula" made on sections of long bone split lengthwise with one end ground into a beveled edge, which Van Heekeren (1972) suggested were suited to "cleaning and scraping the skins of tubers." Similar assemblages of bone tools appeared at other Sampung sites-a total of nineteen caves and rock shelters distributed in the eastern part of the island. Although generally accepted as a Holocene industry, there are currently no firm dates from the majority of these sites. Recent work by Storm (1995), however, has yielded radiocarbon dates on bone taken from faunal and human remains at four east Javanese sites, including Gua Lawa, Wajak, Kecil, and Jimbe. Wajak does not contain evidence of a bone tool industry; dates for the remaining sites are from $3265 \pm 55$ to $2650 \pm 55$ B.P. (see Table 1).

The tool assemblage from the Malaysian site of Gua Bintong was also reported to bear close resemblance to that found at the Sampung sites (Tweedie 1953). Gua Bintong is the only site in Peninsular Malaysia to yield a large component of bone and antler implements - 47 were recorded by Collings (1937). While this site is itself also undated, in a neighboring cave in the same massif, Bukit Chuping, a marine terrace $3 \mathrm{~m}$ above current sea level has been dated to $5200 \pm 200$ B.P. (Haile 1971), making it possible to provisionally place occupation of Gua Bintong to around this same period. Bone tools have now been found on the peninsula at other sites, such as Bukit Tengku Lembu, Gua Madu, Gua Harimau, Gua Tok Long, and Gua Kechil, but occurrences are rare and frequencies low. In East Malaysia, the Niah Caves of northern Sarawak boast one of the largest bone tool assemblages in the region (more than 146 pieces). Although examples of bone technology do appear at Niah right through to the base of excavations, the majority of pieces are clustered within the stratum of deposit thought to be from ca. 10,000-9000 B.P. (Barker et al. 2002; Cranbrook 2000). At Pulau Balambangan, an island cave on the north coast of Sabah, a collection of 33 bone tools, most from a single hearth feature, has been securely dated to between $9960 \pm 190$ B.P. and $8930 \pm 150$ B.P. (Zuraina et al. 1999). Two additional examples of bone implements have come from Hagop Bilo and Madai in Sabah (Bellwood 1988).

Prehistoric assemblages appear to have included bone technology only on rare occasions in the Philippines (Olsen and Glover 2004), though instances have been recorded at Sohoton Cave on Samar Island, the Balobok rock shelter in Tawi Tawi province (Bautista 1999; Olsen and Glover 2004), and Musang Cave in northeast Luzon (Thiel 1990).

On Minahasa, Indonesia, Bellwood (1976) has reported that 17 bone awls were recovered from preceramic levels at the Paso shell midden site. In south Sulawesi, excavation at the cave sites of Ulu Leang 1 and Leang Burung 1 has also yielded significant bone point assemblages comparable in form with those found at other Toalean sites in the southern part of the island (Olsen and Glover 2004), while Van Heekeren (1972) has noted "spatulate" bone implements from several sites. Bellwood et al. (1998) described the occurrence of, chiefly, bone points from work carried out at a number of sites in the northern Moluccas, namely Golo Cave, Siti Nafisah Cave, and Gua Uattamdi. 


\begin{tabular}{|c|c|c|c|c|c|c|c|c|c|c|c|}
\hline SITE & COUNTRY & $\begin{array}{l}\text { APPROXIMATE } \\
\text { DISTANCE TO } \\
\text { MODERN COAST } \\
(\mathrm{km})^{\mathrm{a}}\end{array}$ & $\begin{array}{l}\text { PERIOD OF BONE TOOLS } \\
\text { (UNCALIBRATED B.P.) }\end{array}$ & $\begin{array}{l}\text { MANGROVE } \\
\text { RESOURCES IN } \\
\text { FAUNAL } \\
\text { ASSEMBLAGES }\end{array}$ & $\begin{array}{c}\text { NO. OF } \\
\text { BONE TOOLS }\end{array}$ & 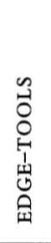 & 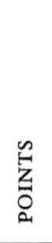 & 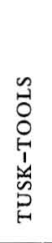 & 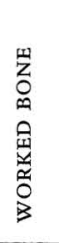 & 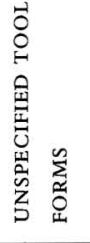 & REFERENCES $^{\mathrm{b}}$ \\
\hline $\begin{array}{l}\text { West Mouth, } \\
\text { Niah }\end{array}$ & E. Malaysia & 16 & $\begin{array}{l}\text { Below deposits dated to } \\
\quad 39,600 \pm 1000 \text { (GR-1339) }\end{array}$ & Present & 3 & $\mathrm{X}$ & & & & & 11 \\
\hline Gan Kira, Niah & E. Malaysia & 16 & $37,500 \pm 2400 \dagger$ & ? & 11 & $\mathrm{X}$ & $\mathrm{X}$ & & $\mathrm{X}$ & & 11 \\
\hline Lang Rongrien & Thailand & 12 & $37,000 \pm 1780$ & $?$ & 3 & & & & & $\mathrm{X}$ & 1 \\
\hline West Mouth & E. Malaysia & 16 & $18,000 ?-8000$ & Present & 79 & $\mathrm{X}$ & $\mathrm{X}$ & $\mathrm{X}$ & $\mathrm{X}$ & & 3,11 \\
\hline Hagop Bilo & E. Malaysia & 25 & $17,000-12,000 \dagger$ & 0 & 1 & $\mathrm{X}$ & & & & & 2 \\
\hline Con Moong & Vietnam & 60 & $\begin{array}{l}11,840 \pm 75(\mathrm{Bln}-1713 / \\
1)-9905 \pm 150(\mathrm{ZK}-380)\end{array}$ & 0 & Present & & $\mathrm{X}$ & & & & 23 \\
\hline $\begin{array}{l}\text { Moh Khiew } \\
\text { Cave }\end{array}$ & Thailand & 13 & $\begin{array}{l}11,020 \pm 150 \text { (OAEP- } \\
1284)-4240 \pm 150 \text { (OAEP- } \\
1290)\end{array}$ & Present & $>5$ & $\mathrm{X}$ & $\mathrm{X}$ & & & & 21 \\
\hline $\begin{array}{l}\text { Lobang Angus, } \\
\text { Niah }\end{array}$ & E. Malaysia & 16 & $\begin{array}{l}\text { Undated-plausibly around } \\
11,000-7000\end{array}$ & Present & 77 & $\mathrm{X}$ & $\mathrm{X}$ & $\mathrm{X}$ & $\mathrm{X}$ & & 11,17 \\
\hline $\begin{array}{l}\text { Agop Sarapad } \\
\text { (MAD 2) }\end{array}$ & E. Malaysia & 7.5 & $11,000-7000^{c}$ & Present & 1 & & & & & & 3 \\
\hline $\begin{array}{l}\text { Pulau } \\
\text { Balambangan }\end{array}$ & E. Malaysia & $<5$ & $9960 \pm 190$ (Beta-109141) & Present & 33 & $\mathrm{X}$ & $\mathrm{X}$ & & & & 22,33 \\
\hline Sakai Cave & Thailand & 40 & $\begin{array}{l}8700 \pm 190 \text { (OAEP- } \\
1370)-7869 \pm 280 \text { (OAEP- } \\
1366)+ \text { modern }\end{array}$ & Present & $>7$ & $\mathrm{X}$ & $\mathrm{X}$ & & & & 21 \\
\hline Gua Song Terus & E. Java & 12 & $8340-5770$ & $?$ & Present & & & & & $\mathrm{X}$ & 7 \\
\hline $\begin{array}{l}\text { Madai (MAD } \\
1 / 28)\end{array}$ & E. Malaysia & 7.5 & 7000 & Present & 0 & & & & $\mathrm{X}$ & & 9 \\
\hline Da But & Vietnam & 40 & $\begin{array}{l}6460 \pm 60(\mathrm{~B} \ln -3510 / \\
2)-5710 \pm 60(\mathrm{~B} \ln -3507 / 1)^{\mathrm{c}}\end{array}$ & Present & Present & & & & & $\mathrm{X}$ & 16,23 \\
\hline Sai Yok 1 & Thailand & 80 & Relative dating $7000-9000$ & ? & 15 & & $\mathrm{X}$ & & & & 30 \\
\hline
\end{tabular}




\begin{tabular}{|c|c|c|c|c|c|c|c|c|c|c|c|}
\hline Gua Song Keplek & E. Java & 12 & $6000-4500$ & $?$ & Present & $\mathrm{X}$ & $\mathrm{X}$ & & & & 7 \\
\hline Gua Bintong & W. Malaysia & 18 & Undated-plausibly around 5200 & Present & $>42$ & $\mathrm{X}$ & $\mathrm{X}$ & $\mathrm{X}$ & & & 4,8 \\
\hline Gua Harimau & W. Malaysia & 100 & $\begin{array}{l}4920 \pm 270(\mathrm{GX}- \\
13508)-1760 \pm 195(\mathrm{GX}- \\
13506)^{\mathrm{c}}\end{array}$ & 0 & Present & & $\mathrm{X}$ & & & & 31,32 \\
\hline Gua Kecil & W. Malaysia & 80 & $4800 \pm 800(\mathrm{GX}-0418)$ & 0 & 4 & & $\mathrm{X}$ & $X$ & $\mathrm{X}$ & & 5 \\
\hline Nong Nor & Thailand & 8 & 4500 & Present & 26 & & $\mathrm{X}$ & & & & 14 \\
\hline Khok Phanom & Thailand & 22 & $4000-3500 ;$ post -3300 & Present & 250 & $\mathrm{X}$ & $\mathrm{X}$ & & $\mathrm{X}$ & & 14 \\
\hline $\begin{array}{c}\mathrm{Di} \\
\text { An Son }\end{array}$ & Vietnam & 90 & $\begin{array}{l}3990 \pm 190(\mathrm{TKa}- \\
11541)-3190 \pm 110(\mathrm{TKa}- \\
11819)^{\mathrm{c}}\end{array}$ & Present & Present & & $\mathrm{X}$ & $\mathrm{X}$ & $\mathrm{X}$ & & 18 \\
\hline Ban Kao & Thailand & 100 & $3800-3300$ & $?$ & Present & & $\mathrm{X}$ & & $\mathrm{X}$ & & 26 \\
\hline Ban Lum Khao & Thailand & 300 & $3400-2500$ & 0 & 28 & $\mathrm{X}$ & $\mathrm{X}$ & & & & 22 \\
\hline $\begin{array}{l}\text { Gua Lawa } \\
\text { (Hoekgrot) }\end{array}$ & E. Java & 10 & $3264 \pm 55$ & ? & $>99$ & $\mathrm{X}$ & $\mathrm{X}$ & & & & $6,7,27$ \\
\hline Gua Sireh & E. Malaysia & ca. 60 & $3220 \pm 190$ (ANU-7047) & Present & 2 & & $\mathrm{X}$ & & & & 15 \\
\hline Kecil Cave & E. Java & 10 & $3060 \pm 85$ & $?$ & Present & $\mathrm{X}$ & & & & & 27 \\
\hline Jimbe & E. Java & 20 & $2650 \pm 55$ & $?$ & Present & $\mathrm{X}$ & $\mathrm{X}$ & & & & 27 \\
\hline $\begin{array}{l}\text { Kain Hitam } \\
\text { (Painted Cave) }\end{array}$ & E. Malaysia & 16 & $2300-1045$ & $?$ & Present & $\mathrm{X}$ & $\mathrm{X}$ & & & & 10 \\
\hline Ban $\mathrm{Na} \mathrm{Di}$ & Thailand & 350 & $\begin{array}{l}2420 \pm 80(\mathrm{NZ}- \\
5242)-2,300 \pm 70(\mathrm{NZ}-5239)\end{array}$ & 0 & 55 & & & & & $\mathrm{X}$ & 13 \\
\hline Noen-U-Loke & Thailand & 300 & $2300-1700$ & 0 & 2 & $\mathrm{X}$ & & & & & 21 \\
\hline Tengku Lembu & W. Malaysia & 20 & Undated & $?$ & 2 & $\mathrm{X}$ & & & & & 25 \\
\hline Gua Madu & W. Malaysia & 150 & Undated & 0 & 1 & $\mathrm{X}$ & & & & & 28 \\
\hline Gol Ba'it & W. Malaysia & $?$ & Undated & $?$ & Present & & & & & $\mathrm{X}$ & 19 \\
\hline Gua Tok Long & W. Malaysia & 150 & Undated & $?$ & 15 & $X$ & $\mathrm{X}$ & & & & 22 \\
\hline Gua Betpuruh & E. Java & 12.5 & Undated & $?$ & $>5$ & $\mathrm{X}$ & $\mathrm{X}$ & & & & 29 \\
\hline $\begin{array}{l}\text { Semanding } \\
\text { district sites }^{\mathrm{d}}\end{array}$ & E. Java & 6.5 & Undated & $?$ & Present & $\mathrm{X}$ & & & & & 29 \\
\hline Gua Mardjan & E. Java & ca. 15 & Undated & $?$ & Present & $\mathrm{X}$ & & & & & 29 \\
\hline $\begin{array}{l}\text { Gunung } \\
\text { Tjantelan }\end{array}$ & E. Java & 20 & Undated & $?$ & Present & $\mathrm{X}$ & & & & & 6 \\
\hline $\begin{array}{l}\text { Sodong rock } \\
\text { shelter }\end{array}$ & E. Java & ca. 15 & Undated & Present & 18 & $\mathrm{X}$ & $X$ & & & & 29 \\
\hline
\end{tabular}




\begin{tabular}{|c|c|c|c|c|c|c|c|c|c|c|c|}
\hline SITE & COUNTRY & $\begin{array}{c}\text { APPROXIMATE } \\
\text { DISTANCE TO } \\
\text { MODERN COAST } \\
(\mathrm{km})^{\mathrm{a}}\end{array}$ & $\begin{array}{l}\text { PERIOD OF BONE TOOLS } \\
\text { (UNCALIBRATED B.P.) }\end{array}$ & $\begin{array}{l}\text { MANGROVE } \\
\text { RESOURCES IN } \\
\text { FAUNAL } \\
\text { ASSEMBLAGES }\end{array}$ & $\begin{array}{c}\text { NO. OF } \\
\text { BONE TOOLS }\end{array}$ & $\begin{array}{l}3 \\
0 \\
0 \\
0 \\
0 \\
1 \\
0 \\
0 \\
0 \\
0\end{array}$ & 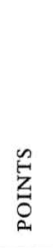 & $\begin{array}{l}0 \\
0 \\
0 \\
\circ \\
0 \\
0 \\
0 \\
0\end{array}$ & 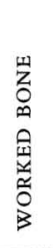 & 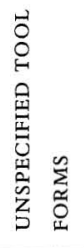 & REFERENCES ${ }^{\mathrm{b}}$ \\
\hline Kramat Cave & E. Java & 40 & Undated & ? & Present & $\mathrm{X}$ & & & & & 29 \\
\hline Lawang Cave & E. Java & 40 & Undated & $?$ & Present & $\mathrm{X}$ & & & & & 29 \\
\hline $\begin{array}{l}\text { Sampung (Guwo } \\
\text { Lowo) }\end{array}$ & E. Java & 44 & Undated & ? & Present & $\mathrm{X}$ & $\mathrm{X}$ & & & & 6,27 \\
\hline Da Phuc & Vietnam & 30 & Undated & $?$ & 105 & $\mathrm{X}$ & $\mathrm{X}$ & & & & 12 \\
\hline Hang Bung & Vietnam & $?$ & Undated & $?$ & Present & & & & & $\mathrm{X}$ & 20 \\
\hline Xom Trai & Vietnam & 65 & Undated & ? & Present & & & & & $\mathrm{X}$ & 24 \\
\hline
\end{tabular}

${ }^{a}$ Where literature references have not been available the approximate distances of sites to the modern coastline have been calculated by reference to local place names and with the aid of National Geographic MapMachine.

${ }^{b}$ References: 1. Anderson 1988; 2. Barker et al. 2002; 3. Bellwood 1988; 4. Collings 1937; 5. Dunn 1964; 6. Erdbrink 1954; 7. Forestier 1999; 8. Haile 1971; 9. Harrison 1998; 10. Harrisson 1967; 11. Harrisson and Medway 1962; 12. Ha Van Tan 1978; 13. Higham and Kijngam 1984; 14. Higham and Thosarat 1998; 15. Datan 1993; 16. Kohl and Quitta 1978; 17. Medway 1966; 18. Nishimura and Nguyen 2002; 19. Olsen and Glover 2003; 20. Pawlik in press; 21. Pookajorn et al. 1996; 22. Rabett 2002; 23. Reynolds 1990; 24. Shoocondgej 1996; 25. Sieveking 1962; 26. Sørensen 1999; 27. Storm 1995; 28. Tweedie 1940; 29. Van Heekeren 1972; 30. Van Heekeren and Knuth 1967; 31. Zolkuranian 1989; 32. Zuraina 1998; 33. Zuraina et al. 1999.

${ }^{\mathrm{c}}$ Dates may not correspond exactly to the period of bone tool use.

${ }^{\mathrm{d}}$ Gua Gedah, Gua Kandang, Gua Ketjil, Gua Bale, Gua Pawon, Gua Bagnong, Gua Peturon, Gua Butol, Gua Pangang. 
Bone implements have also been reported as a small component of the Hoabinhian sites in Vietnam (Matthews 1966; Reynolds 1990). Ha Van Tan (1999) reported a total assemblage of approximately 250 implements from 150 different localities, but 105 of these (mostly points or awls) were from one northern site, Da Phuc (Higham 1989; Matthews 1966; Pham Huy Thong et al. 1990). Remaining instances within the Hoabinhian appear to have been spread much more thinly (Van Heekeren 1972). Bone tools are known from later Holocene Bacsonian contexts, but again occurrences are not common: Matthews (1966) reported seven instances (out of at least 54 sites), but stressed that at no time were any more than two implements found. A sizable bone tool assemblage has, however, been recovered from the mid Holocene sites of Da But-which is also said to bear similarity to the Sampung material (Bui 1991; Shoocongdej 1996; Tweedie 1953) — and An Son (Nishimura and Nguyen 2002).

In Thailand, in addition to the antler artifacts recovered from Lang Rongrien, significant assemblages dating to between the terminal Pleistocene and mid Holocene have appeared at Khok Phanom Di (Higham 1993), Nong Nor (Higham et al. 1998), Moh Khiew and Sakai (Pookajorn et al. 1996), and Ban Kao (Sørensen and Hatting 1966), and from the preceramic levels (post-dating 7000-9000 B.P.) at Sai Yok I in western Thailand (Sørensen 1988; Van Heekeren and Knuth 1967). Other occurrences include single points from the Banyan Valley cave in northwestern Thailand (Reynolds 1992) and Tham Pra (Pra cave) in the north (Sarasin 1933).

A detailed study of bone technology and its occurrence between ca. 11,000 and 4000 B.P. for Sundaland exclusively ${ }^{4}$ found that sites yielding a bone tool component appeared to be quite frequently located on or near the coast and contain an element of faunal remains from this environment (Rabett 2002; Table 1). The exact reason why this technology might have come to be particularly associated with coastal exploitation is not yet clear. The availability of suitable lithic raw materials is a commonly cited reason to explain the appearance of bone-based technologies. However, while this may well remain a factor, it can by no means be taken as a given. Evidence from Pulau Balambangan, for example, clearly demonstrates the concurrent use of local chert and bone in the technical systems (Zuraina et al. 1999).

Variation in the occurrence of bone technology between interior and coastal sites could be representative of the differential preservation of organic remains between these two areas. However, this seems unlikely given that at many inland cave sites ${ }^{5}$ there is good faunal preservation yet a complete absence of bone technology. An additional variable is the extent to which bone tools have been misidentified or overlooked by archaeologists in the past. In my own work there have been cases where bone fragments, previously identified as "tools," have been proven unlikely to be so; conversely, study of faunal remains has periodically yielded bona fide tools that had not been unidentified hitherto.

The distribution of tools, therefore, assuming that it is not a function of differential survival, implies that the development of bone as a technological resource may have been tied to environmental changes occurring during the PleistoceneHolocene transition. It is possible that a progressive rise in sea level brought coastal resources within the foraging range of local inland groups who had been previously subsisting off rainforest and lacustrine foods, ${ }^{6}$ perhaps stimulating an 
increased role for bone implements as a means to extract these new resources. Alternatively, sites that are currently within foraging distance of the sea may well be only the most recent manifestation of a longer tradition of coastal settlement and subsistence strategies. The credibility of this scenario is supported by the fact that several bone tool-yielding sites, such as Ban Kao (Sørensen 1999), Da But (Bui 1991), and An Son (Nishimura and Nguyen 2002), which are now some distance inland, were occupied during the period of elevated sea levels in the mid Holocene and exhibit faunal assemblages that incorporate coastal resources.

It is possibly significant in relation to coastal exploitation that rising sea levels between ca. 10,000 and 5000 B.P. have now been shown to coincide with an expansion of mangrove swamps along stretches of the regional coastline (Allen 1996; Grindod et al. 2002). Mangrove forests thrive along tropical shorelines that are protected from severe wave action and along which large quantities of riverborne sediments are being deposited. They colonize the upper part of the intertidal zone and at low tide are often fronted by exposed tidal flats. In terms of their value to human subsistence, mangrove forests serve as important nursery, foraging, and refuge areas for a wide range of fish and invertebrates (Dunn and Dunn 1977; Rönnbäck 1999). Presumably the expansion of mangrove forests encouraged local foraging communities to focus more on coastal marine and estuarine fauna in their diets. Meehan (1982) reports that modern littoral foragers in northern Australia historically used pointed bone pieces to pick out oyster flesh, but aside from this, bone did not figure greatly in the gathering-tool inventory. Collecting shellfish was carried out, predominantly by women, with the aid of a 1.5-m-long wooden digging stick, usually made on the spot, making it unlikely that bone tools were directly employed in the collection of mangrove or estuarine mollusks. Nonetheless, although further research is clearly required, the archaeological evidence of bone technology assembled in Table 1 begins to suggest a link between prehistoric bone technologies and subsistence strategies in this environment.

The post-Pleistocene spread and exploitation of mangrove forests have been extensively studied for the North Arnhem Land area of Australia, and reference to these provides some thought-provoking possibilities for the Southeast Asian bone tool data. Along the coastline of northern Australia there was a fairly rapid rise in sea level after 18,000 B.P., before it began to stabilize ca. 6800 B.P. (Woodroffe et al. 1988). Landform evolution in the area of the South Alligator River shows that tidal waters began to penetrate up the river valley ca. 8000 B.P. Embayments silted up rapidly and mangrove forest began to expand at the expense of landward terrestrial forests. After 5300 B.P., however, the mangrove receded quickly and had largely disappeared by ca. 4000 B.P., giving way to saline mudflats and freshwater swamp. Three rock shelters along the East Alligator River were occupied during this major phase of mangrove growth: Malangangerr, Nawamoyn (dated to $5980 \pm 140$ B.P. and $7110 \pm 130$ B.P. respectively; Allen 1986), and Padypadiy. They all contained well-stratified middens made up of mainly estuarine and mangrove shellfish. At all three, lithic technology was found to be sparing when compared to typologically related plateau sites approximately $32 \mathrm{~km}$ inland. However, they did yield shell artifacts (of the mangrove shell Geloina jukesi), wooden implements, and, significantly, bone tools throughout the deposits. These latter comprised small unipolar and bipolar points, "spatu- 
lated points," and spatulae (Allen 1986; White and Peterson 1969). An ethnographically derived model of seasonal mobility incorporating these and the plateau sites suggested that bone technology may have featured prominently in dryseason fishing activities alongside wooden and bone-tipped tridents used for catching fish, water snakes, and waterfowl, with stone-tipped spears being employed to hunt larger game in the wet season (White and Peterson 1969).

\section{PREHISTORIC TOOL USE: METHODOLOGY}

Having assessed the distribution of bone technology through Southeast Asia and across Sundaland in particular, and having gained some broad idea of the kinds of uses to which these tools may have been put, in the rest of this paper I shall consider the tools themselves in greater detail.

By the mid Holocene (ca. 4000 B.P.), technically complex bone technologysuch as barbed and tanged points, fishing hooks, and hafted "adzes"-was appearing at sites in the Sunda region. These more complex tools appear to have been added to (or developed from) existing less formally standardized tool kits. The more amorphous character of these preexisting inventories has contributed to the extent of variation in how they are classified.

The method of classification favored by Collings (1937) was to divide the assemblage of archaeological bone tools from Gua Bintong into three categories according to the extent of their apparent working: "axes" (evenly shaped all over); those pieces that were "unevenly shaped"; and those "made on split bone." In their study of the Niah specimens, Harrisson and Medway (1962) relied more closely on variations in shape and size, and at times the raw material on which tools were made, as distinguishing features between classes such as "spatulas" and "gouges." The former term has been used more inclusively by Zuraina et al. (1999) in reference to tool forms from Pulau Balambangan. In this case all nonpointed bone tools are referred to as "spatulae." Regional ethnographic instances of bone tools described by the term "spatula" generally refer to utensils used either in culinary contexts or in the preparation of betel for chewing (e.g., Strathern 1969). On these ethnographic pieces the articulation is present and it is here that the tool is grasped. The split revealing the ventral cavity at the other end extends halfway back along the tool, and is for the most part at a very shallow oblique angle and almost flush at the tip. It does not appear to be sufficiently similar to the archaeological specimens for useful parallels to be drawn.

In order to objectively standardize observations across different collections, the methodology I devised first divided assemblages into "point" and "edge-tool" categories based on a simple mathematical expression of the shape of the tip or leading edge (following Lampert 1966). Additional, nonfunctional headings were used for pieces that could not be classified easily by this method, such as "tusktools." Each archaeological specimen was examined using a portable Zenith STZ-4500 Trinocular light microscope (15-120× magnification). A stringent set of data-entry assumptions was adhered to as each piece was then further classified according to the number of manufacturing stages evident (for example, from primary manufacture to the manner and extent of secondary carving, shaping, hafting, and so on) and according to its calculated level of tool exploitation. The "exploitation ratio" was defined as a measure of how efficiently a tool had been used 
relative to the amount of work that had gone into manufacturing it (adapted from Choyke 1997). Taken together, these two elements formed the second level of classification and were employed to identify manufacturing habits both within and between bone tool assemblages.

A final stratum of classification considered tool functionality specifically by identifying the distribution and form of use-wear traces (predominantly, the location and manner of appreciable surface polishing, but also the presence of micro- and macroflaking, and so on). Second- and third-order classification was determined by using a very detailed descriptive system designed to quantify all observable manufacturing and use-wear characteristics present on each artifact, including the orientation of manufacturing striations, the form and location of modification deemed to be repair or reworking efforts, and varying forms of surface polish. These observations were made in full knowledge of, and with allowances for, the potential influence of taphonomic modification to the bone.

The approach is not without limitations. For example, the reduced emphasis on morphological characteristics may have oversimplified the significance of tool shape. However, the combined system of classification is based on how tools were made and deployed, providing the analyst with the potential to determine if segments of an assemblage were manipulated in similar or differing ways, largely independent of formal typological variation (a significant issue when considering the decision-making processes involved in tool manufacture and maintenance). The approach also requires very short inferential jumps to be made by the analyst. The range of actions visible on each tool, rather than any preconception of its potential functionality, is the key determinant in deciding its categorization. Although there is still definitely room for refinement, this three-order system of classification represents a viable starting point from which to integrate archaeological bone technologies into discussions about subsistence behavior, at both a technical and a behavioral level.

\section{PREHISTORIC TOOL USE: EDGE-TOOL FORMS}

A combination of ethnographic and experimental studies employing this methodology was carried out by the author to further elucidate understanding about bone tool functionality and maintenance. Examination of the mechanical character of bone ${ }^{7}$ suggests that as a technical material it is well suited to use contexts where loading is applied down the length of a tool. Furthermore, any tool in leverage is subjected to tensile loading on one side and simultaneously to compressive loading on the other. Bone, which has comparable values for both properties, is more durable under such loading than materials that have mechanical characteristics that bias them to one or another of these properties, such as bamboo. Through experimentation, for example, it was established that hafted bone implements with a beveled leading edge make effective wood chisels when used with a hammer stone (Fig. 1). When terminal damage occurred (Fig. 2), it tended to correlate with the kind of work that was being carried out. Transverse breaks seemed to result when resistance at the leading edge, such as from a knot, was encountered. Most fractures, however, appear to have been diagonal-longitudinal. These were formed when excessive rotational stress was applied at the back of a tool, for example, in order to lever away partially embedded sections of wood. The use of 


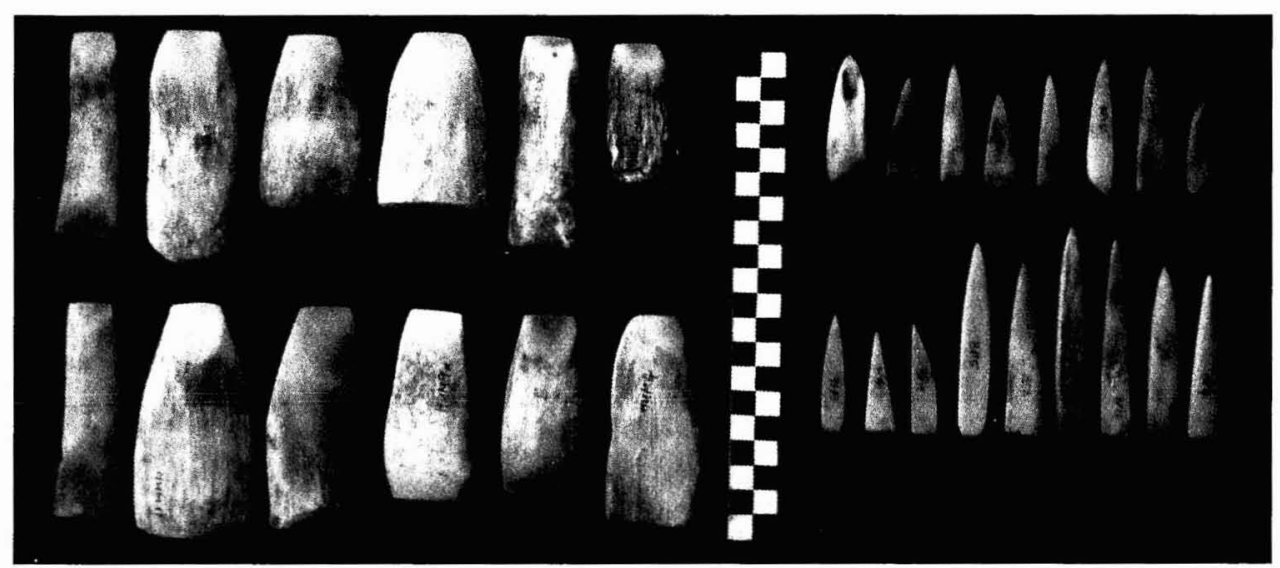

Fig. 1. Experimental edge-tools and points prepared by the author on boiled domestic pig bone. Scale in $5 \mathrm{~mm}$ increments. (Photograph: Ryan Rabett)

hafted bone tools in digging experiments rarely produced terminal fractures, but exacted noticeable changes in tool shape, resulting in many longitudinal striations and reductions in tool length (Fig. 3). It is, however, acknowledged that the extent of any such traces will be significantly dependent on the nature of the contexts being dug (in this case, exclusively stony Red Devonshire clay).

A pattern of fracture damage consistent with that appearing on the experimental woodworking tools was apparent on the specimens I examined from archaeological sites. Here I shall focus on material from two sites: Pulau Balambangan and Khok Phanom Di (Fig. 4: tools 1-3). The work carried out at Pulau Balambangan (Zuraina et al. 1999) has shown that during the period when the vast majority of the bone tools was deposited, mangrove mollusks appear at the site for the first time. At this point the cave appears to have been used as some kind of production camp, with the item or items being produced apparently demanding robust bone implements (probably made from deer bone). Most tool elements seem to have been imported from elsewhere, given a general lack of evidence for on-site production, and were steadily used up with little effort expended on repair. Retooling apparently took place around the hearth that was discovered in the excavation. Older fractured tool heads were removed and thrown into the fire (an act not without significance of its own, possibly an informal but ritualistic act of disposal), and the tool shafts probably were refitted with new heads. The simple hafting features of the edge-tools could be taken to suggest that this kind of routine was anticipated ahead of time. The fact that most bone tools from the site were found in the hearth may also imply that this was a group activity, undertaken (judging from the associated faunal material) perhaps while eating. Further lines of evidence will be important here to refute or expand upon these ideas, but based on current information and given the site's location, targeted exploitation of particular mangrove trees looks to have been an important reason for going there.

The more recent site of the two, Khok Phanom Di, was also located in close proximity to local mangrove forests. The early occupation was marine-oriented, 


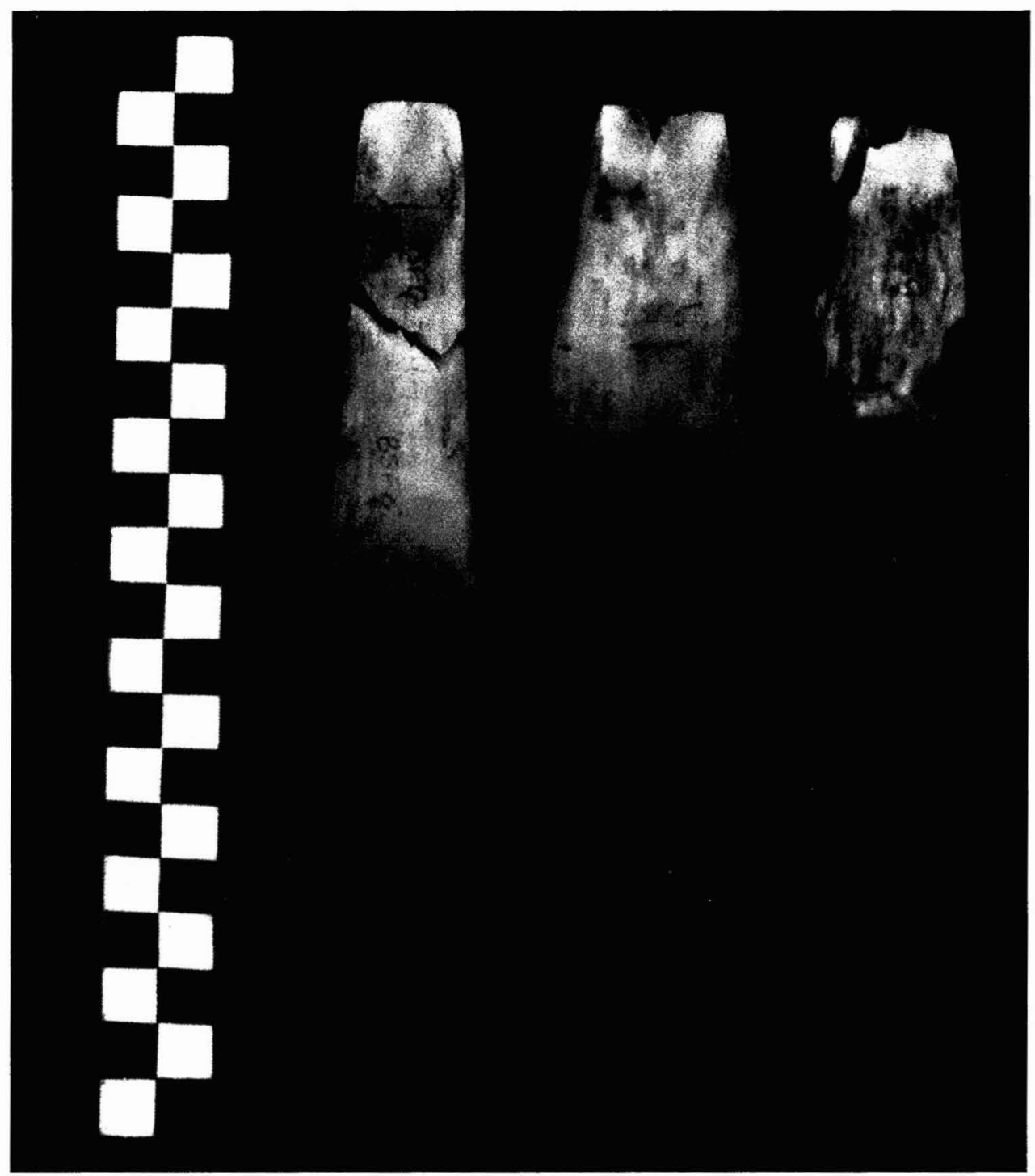

Fig. 2. Examples of fracture damage on experimental bone tools used in woodworking. Scale in $5 \mathrm{~mm}$ increments. (Photograph: Ryan Rabett)

though freshwater mollusks and some terrestrial mammals were also taken (Higham and Maloney 1989). During the later phase of occupation, there was a noticeable shift, associated with the recession of sea levels (Higham and Bannanurag 1990), in the local environment to one dominated by forest and freshwater swamp, accompanied by an increased emphasis in the subsistence system on terrestrial fauna. It is interesting that despite this marked change, bone technology continued to play a significant role in activities taking place at the site. It is from this later period that bone edge-tools, always present, became more prominent. These implements were originally described (Higham 1993) either as weaving 


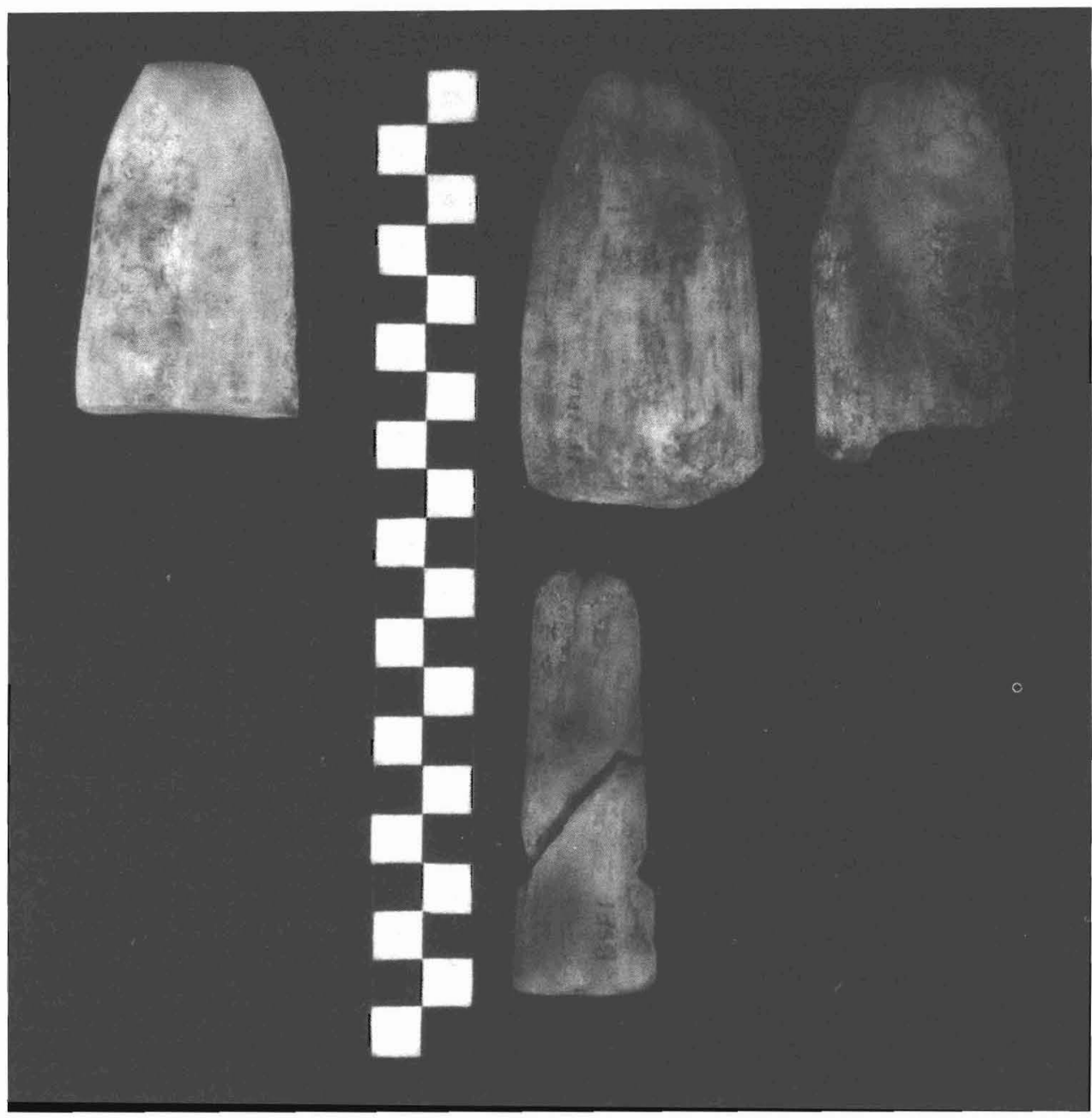

Fig. 3. Examples of damage and rounding of profile on (hafted) experimental bone tools used as digging implements; the tool on the left is unused for comparison. Scale in $5 \mathrm{~mm}$ increments. (Photograph: Ryan Rabett)

"bobbins," on account of common formal and wear characteristics reminiscent of such tools, or as "burnishers" through comparison with experimental work carried out by Semenov (1964). Reexamination of the material, however, suggests that some specimens could have been hafted tools on the evidence of fine usewear striations to the rear cortical bone caused by movement of particulate matter in a binding, as well as particular attention to modifying the rear portion of implements. The fact that most instances of fracturing were diagonal or longitudinal, often cutting through the utilized edge, suggests that the damage was from a different kind of use than burnishing, consistent with (though not necessarily confined to) woodworking activities, though a specific connection to mangrove exploitation is less evident than in the case of Pulau Balambangan. 


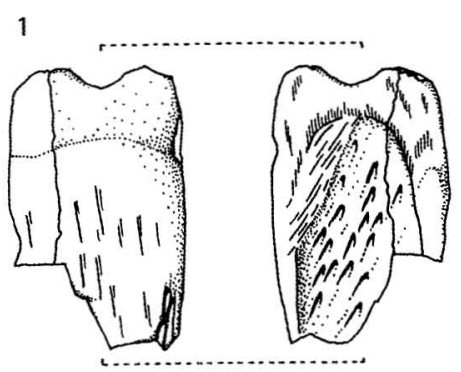

2

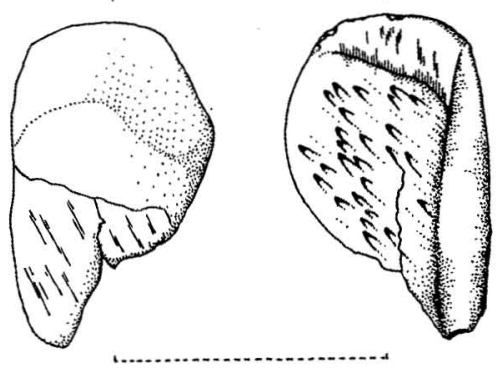

3
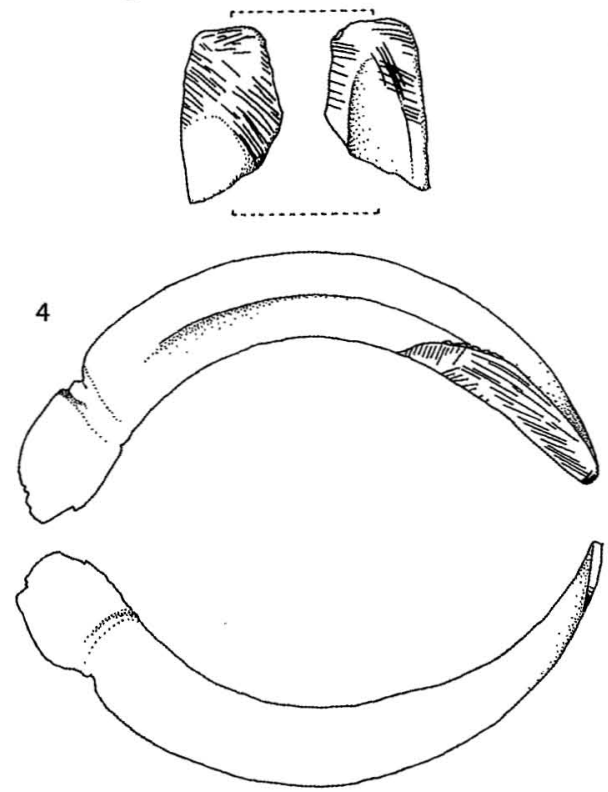

Drawing by RJR

Fig. 4. Bone woodworking tools. Tools 1 and 2 are from Pulau Balambangan (Universiti Sains Malaysia), Tool 3 is from Khok Phanom Di (Prachinburi National Museum), and Tool 4 is an ethnographic piece collected from Papua New Guinea recorded in 1903 as a "carving tool" (1903.55.46Rohn Collection, Pitt Rivers Museum, Oxford).

The precise function of such edge-tools in the context of mangrove or indeed coastal subsistence strategies remains elusive. Aside from their modern use as lumber, mangrove plants serve as a standing pharmacopoeia for indigenous groups and as a ready source of materials for making tools such as digging sticks, spears, paddles, and fish and crab traps (Meehan 1982; Rönnbäck 1999). Mangrove trees, such as Camptostemon schultzii, with light, buoyant wood are also cut to build simple, often impromptu, rafts to enable hunting parties to navigate tidal creeks and river channels within the mangrove (Akerman 1975b; Jones 1989; Love 1939; Roth 1908). Bone tools do not appear to figure in the construction of these vessels in regional ethnographies (e.g., Akerman 1975a; Love 1939), but there is ethnographic and experimental evidence elsewhere that bone implements are suitable for the removal of bark in canoe and bucket construction (Johnson et al. 2000; Scheinsohn 1997; Scheinsohn and Ferretti 1995), indicating the feasibility of such a technology even if the environments concerned are disparate.

While almost no examples $(n=1)$ have been found among the bone edgetools from any of the caves in the Niah complex that can be interpreted along the same lines as those from Pulau Balambangan and Khok Phanom Di, this is 
not to say that woodworking activities did not figure at Niah. The longitudinally split edge-tools (defined by Harrisson and Medway [1962] as "gouges"), which appear to have been made regularly of primate femora or humeri, are no longer available to study, but from the published illustrations they appear comparable with regional ethnographic woodworking tools. For example, the Koko Tai'yuri of the northern Queensland coast used bone gouges made from emu and kangaroo tibiae to hollow out the soft wood of the tree Gryocarpus jacquini for the purposes of carrying water (Thomson 1936).

Aside from these implements there is also evidence at Niah that some woodcrafting or wood-finishing tasks may have been carried out using a different material altogether, namely the sharpened lower canines of pigs (probably Sus barbatus). Numerous ethnographic comparisons are available for such tools, particularly from Papua New Guinea (Fig. 4: tool 4; Fig. 5), where they are recorded as having been used in the carving and planing of bow hafts and spear shafts. Similar activities can be tentatively inferred from the archaeological specimens (Rabett 2004). At Niah, tusks were split longitudinally and then worked on the outside of the curve to create a blade, or else they were left whole with one or both sides of the inner curve honed to an edge. There is evidence for the utilization of pig tusks at other Southeast Asian sites such as Gua Bintong and Gua Kechil, but it is noticeably absent in most cases. This carries implications in terms not only of the kinds of activity taking place at Niah, but also of the deliberate selection of particular tool materials for particular jobs.

A different kind of archaeological split-bone tool was recovered from a cave local to Niah, called Kain Hitam (Fig. 6: tool 1). This implement (fabricated on a primate femur) retains remnants of the distal articulation at the back of the tool and has a slightly rounded leading edge. It is very similar to three museum pieces from New Guinea cataloged as having been used for "planting yams" by the original collector, B. Blackwood, in 1937 (e.g., Fig. 6: tool 3). Potentially, some of the broken split-bone implements that make up a significant proportion of the edge-tools from Niah (e.g., Fig. 6: tool 2) could have been used in similar activities. Indeed, analysis based on the exploitation ratio of these implements, as well as apparent similarities in form compared with ethnographic and experimental pieces, suggests that most of the edge-tools from Niah were possibly employed in digging activities. This is also something of an enigma, for it does not look as though such implements would have been used for mangrove or coastal foraging and begins to raise the question of whether some kind of "horticultural" activity was taking place at Niah during the early Holocene (see also this volume: Barker and Barton). Digging sticks are a common implement among traditional cultures in Southeast Asia, but most appear to have been made of wood and are often improvised (Rambo 1985). That said, Endicott $(1979,1984)$ relates how the Batek De' women (a dialect group of Semang Orang Asli in Peninsular Malaysia) use metal-bladed digging sticks for gathering forest tubers. Pookajorn $(1996: 209)$ writes of the Sakai Orang Asli aboriginals of Southern Thailand that "wooden sticks or polished bones [are used] for digging wild yams." Although in this instance it is not clear if reference is being made to bone-tipped or whole-bone digging implements, it is further ethnographic evidence supporting the hypothesis that early tropical foragers used bone digging tools. 


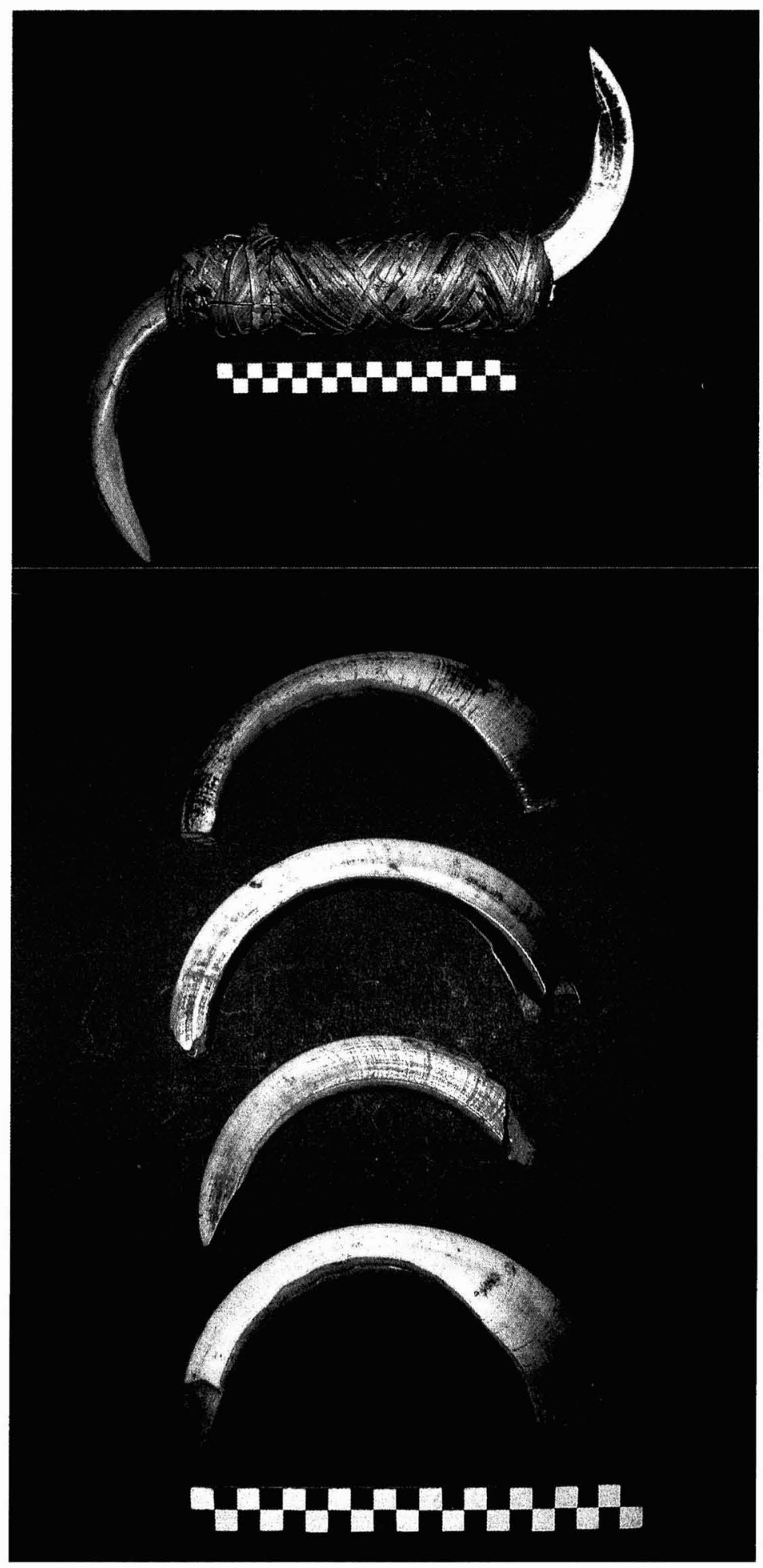

Fig. 5. Ethnographic examples of tusk-tools: (below) unhafted specimens cataloged as having been used for scraping and planing (1968.321.1-4 Wiru, Southern Highlands, Papua New Guinea), and (above) hafted specimens cataloged as having been used for cutting (30.351.b Sepik, Papua New Guinea). Scales in $5 \mathrm{~mm}$ increments. (Reproduced with the kind permission of Cambridge University Museum of Archaeology and Anthropology) 

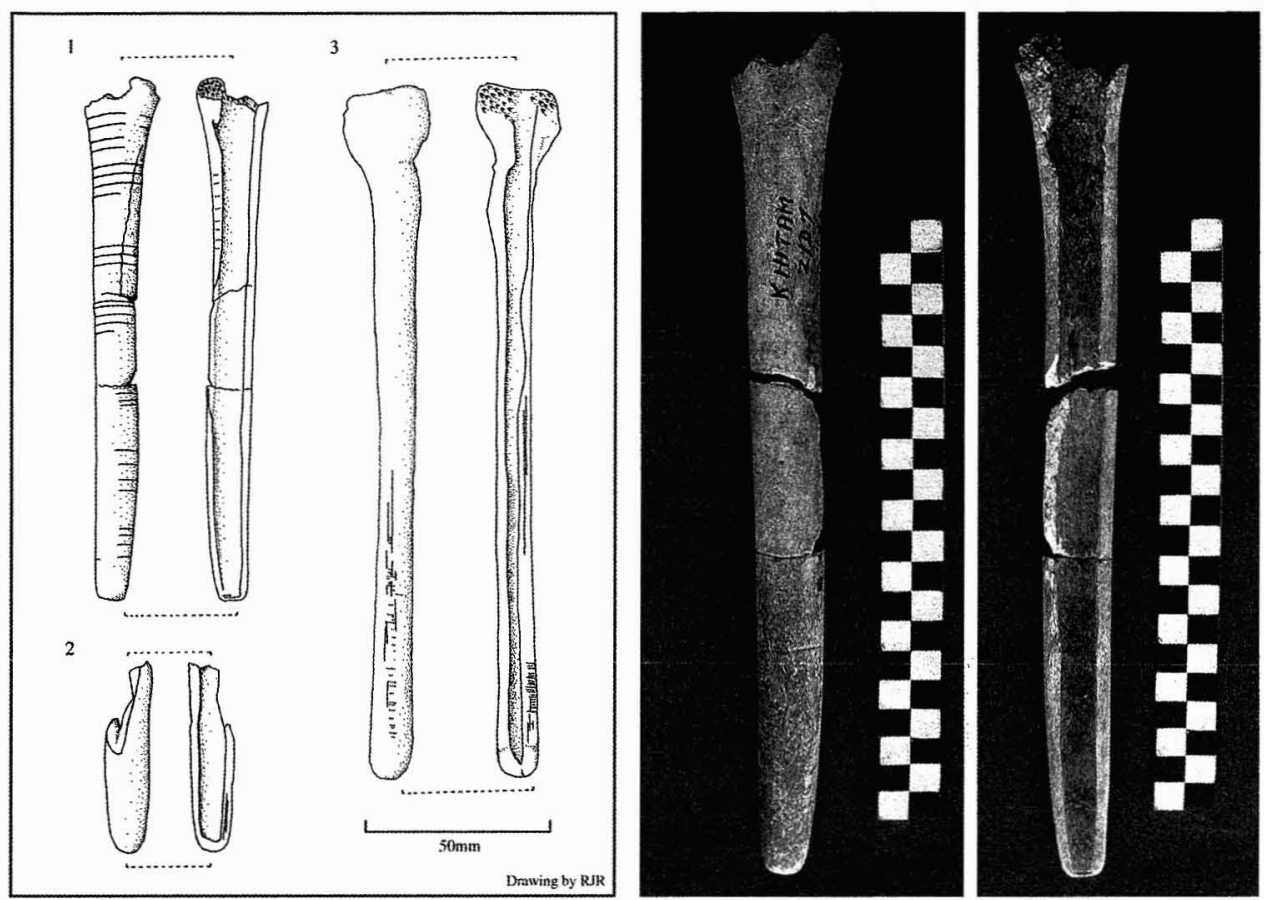

Fig. 6. Bone digging tools. Tool 1 is from Kain Hitam cave near Niah Great Cave (Sarawak Museum) - photographs of this implement are shown on the right (scale in centimeters; photographs: Ryan Rabett). Tool 2 is from the West Mouth excavations in Niah Great Cave (Sarawak Museum). Tool 3 is an ethnographic piece from Papua New Guinea recorded in 1937 as a "tool for planting yams” (1938.36.1534—Blackwood Collection, Pitt-Rivers Museum, Oxford).

\section{PREHISTORIC TOOL USE: POINT FORMS}

Bone points from archaeological sites between the terminal Pleistocene and mid Holocene tend to have a simple tapered shape and were most likely used as awls or projectiles. My experimental work to produce and use comparable forms (Fig. 1) revealed surface characteristics that the methodology was able to isolate. For example, polish from use-wear favored the front section of experimental tools and was quite visible on those points used as awls and less so on those used as projectiles. Although the experimental sample was small $(n=21)$, it is noteworthy that awls tended to show breakage closer to the tip, while projectiles showed, in addition to damage in this area, a significant degree of breakage just outside the haft, a feature that may be attributed to the different forces of impact involved. Given the limited extent of the experiments, further comparative work is needed to bring greater clarity to the study of archaeological specimens, and the following comments should be taken only as preliminary interpretations.

In terms of their classification and form, the bone points recovered from Niah appear to represent a range of projectiles, awls, and pieces of indeterminate use. For example, long ground tubular points (Fig. 7) appear to have been designed for deep penetration and ease of extraction, though the exact context of their use has not yet been established. Polish is confined to the front third of a series of small triangular pieces (Fig. 7). This might signify that they were used as awls, 

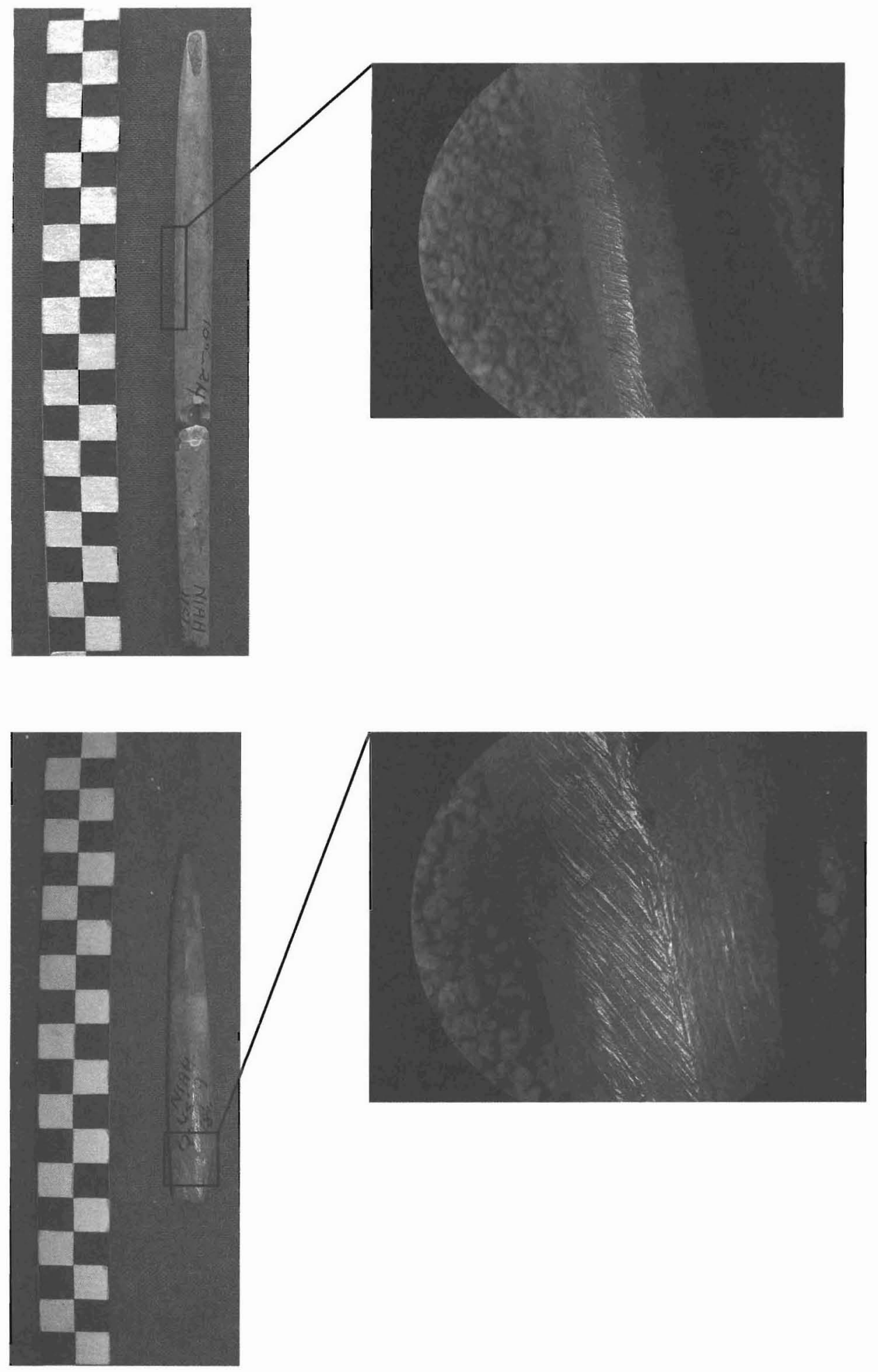

Fig. 7. Two point forms from Lobang Angus, Niah, both showing considerable modification (grinding) to laterals and rear sections. Scales in centimeters. (Reproduced with the kind permission of the Sarawak Museum, Malaysia); photographs: Ryan Rabett. 
but the creation of uniformly convergent laterals suggests otherwise and could imply that they were shallow penetration projectiles, perhaps poison-tipped. ${ }^{8}$

A series of larger scraped tubular points (Fig. 8) from one of the Niah Caves (Lobang Angus) and from Khok Phanom Di suggests use in a different context. Ethnographic evidence from both Australia and the Andaman Islands relates how pieces such as these, called "self-barbed" bone points, were often associated with spearing or hooking fish (Lampert 1966; Pokines and Krupa 1997; Thomson 1936), though in closed rainforest in South America the same kind of point ${ }^{9}$ is used to kill birds and small terrestrial animals (Chagnon 1992; Hames 1979). The appearance of these points at Lobang Angus in the mid Holocene appears to have coincided with a noticeable increase in fish remains, and since localized flooding is a feature of the environment in the vicinity of the site even today (Harrisson 1966), it is a reasonable proposition that a harpoon technology was employed in antiquity for fishing.

Compared with the predominance of markedly modified projectiles at Niah, the point forms from Moh Khiew and Sakai caves in southern Thailand (probably awls) appear to have been made on opportunistically shaped bones. On the other hand, reexamination of a sample $(n=15 / 89)$ of point forms classed as "microawls" (Fig. 8: tools 2-6) from Khok Phanom Di (Higham 1993) suggests that many if not all of these small pieces could have been hafted and possibly produced to a standardized template. An alternative interpretation consistent with those details would be that they do not represent separate tools, but rather may be the bone tips of pronged arrows or spears. Such implements (with or without tips) have been documented ethnographically as used against birds, bats, or small land animals (Griffin 1997; Sillitoe 1988), though the more common use for pronged spear/arrows is for fishing (Blackwood 1950; Lampert 1966; Mulvaney and Kamminga 1999; Oswalt 1976; White and Peterson 1969). Drawing chiefly on Australian ethnographic accounts, bone bi-points and uni-points very similar to those found at Khok Phanom Di are quite frequently documented as leister tips (Davidson 1934; Lampert 1966; Mulvaney and Kamminga 1999).

Khok Phanom Di was well positioned to exploit both the local mangroves and the nearby Bang Pakong estuary. Bone points recovered from the earliest period of occupation at this site included fishing hooks and a small number of quite complex harpoon points, confirming (along with the appearance of pierced clay net-sinkers) the importance of fishing during this time. Despite local environmental change and a marked increase in mammalian fauna during subsequent occupation, it appears that fishing technology continued to feature prominently, with the hooks and harpoons being replaced, apparently, by bone-tipped leisters.

\section{CONCLUSION}

Between 11,000 and 4000 B.P., when evidence for the use of bone technology first rises to prominence in Southeast Asian cave and open-air sites, there are indications that it may often have been quite closely associated with coastal occupation and exploitation strategies. An apparently recurrent association with mangrove resources implies a particular link to this habitat. The presence of tools that can be ascribed to woodworking and digging activities at many sites invites speculation about their exact uses; a link to the fabrication of water-carrying vessels or 

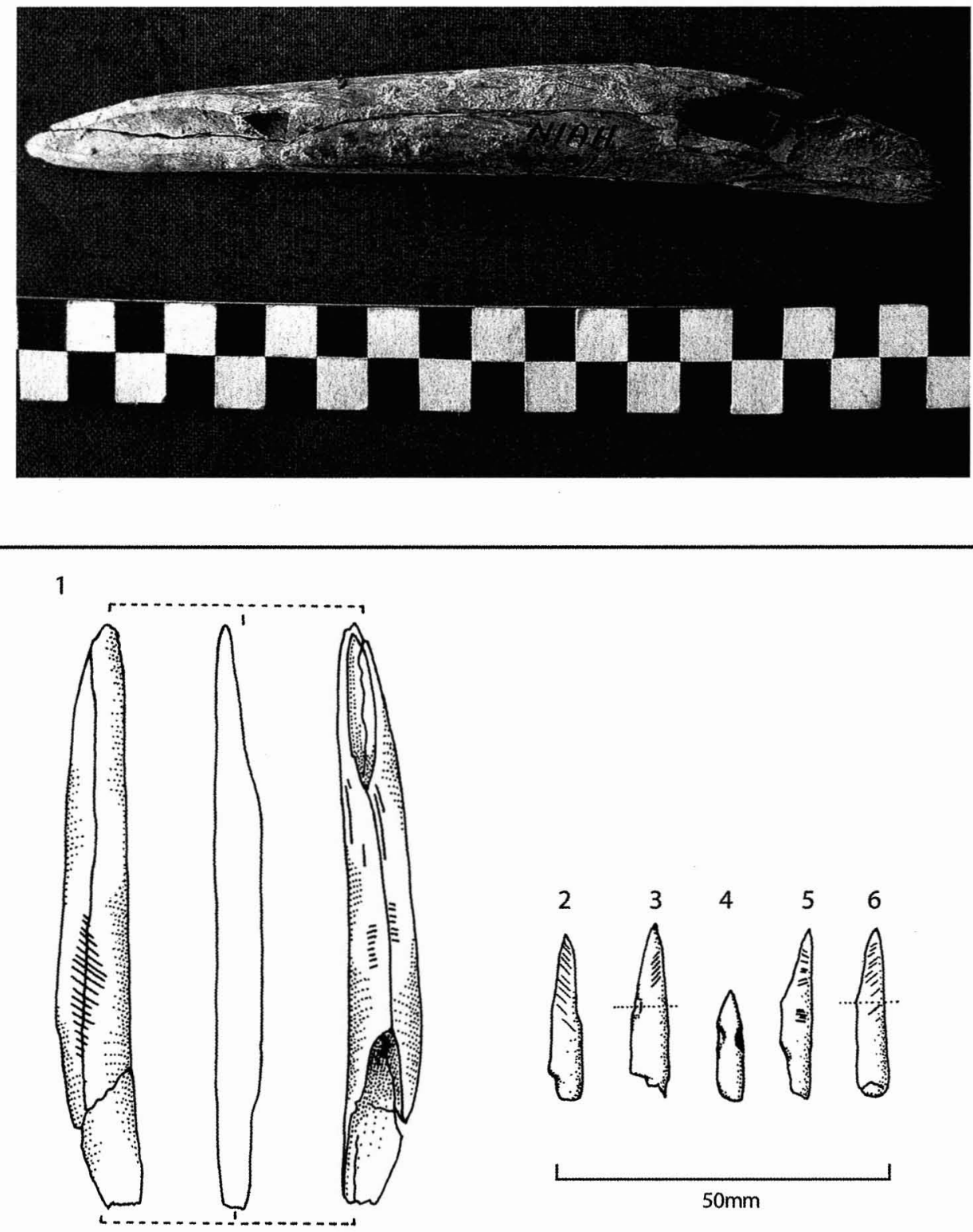

Drawing by RJR

Fig. 8. Bone projectile points. Tool 1, from Lobang Angus, is interpreted as a "self-barbed" harpoon point; photograph of this implement is presented at the top (scale in centimeters; photograph: Ryan Rabett). Tools 2-6 from Khok Phanom Di have been interpreted as leisters (Prachinburi National Museum). (Reproduced with the kind permission of the Sarawak Museum, Malaysia) 
even watercraft may be applicable in some cases. The production and use of fishing implements made from bone (whether fishhooks, harpoons, or leisters) also appear to have been important. It must be stressed that not all excavated coastal sites in Sundaland have yielded bone implements, and whether or not this fact can be attributed to the distribution of ancient mangrove habitats is a matter for future research. Settlement at some of the larger known shell midden sites, such as the Hinai sites in northern Sumatra (McKinnon 1991), may simply have not required the use of this kind of technology, just as modern shellfish gathering is not heavily reliant upon it. What is increasingly apparent, however, is that prehistoric foragers in this region had a good working understanding of the mechanical properties of bone and utilized bone implements as conditions and needs suited the parameters of this material. Research into the suitability of bone from different species and elements in tool making may well permit both a finer-grained understanding of this technology and the place it held in early tropical subsistence.

\section{ACKNOWLEDGMENTS}

I owe thanks to many people for their support during the original doctoral research out of which this paper has been devised, but particular thanks must go to Zuraina Majid, Zulkifli Jaafar, Ipoi Datan, Surin Pookajorn, and Rasmi Shoocongdej in Southeast Asia, and to Preston Miracle, Anita Herle, and Lynn Parker in England. My doctoral research was made possible by a University of Cambridge Research Maintenance Grant and by a generous award from the Evans Award Fund of the University of Cambridge; the assistance of both funding bodies is gratefully acknowledged. In presenting this research in its current form I would also like to thank Graeme Barker for his advice and encouragement; Ian Glover, Vivian Scheinsohn, and Paul Storm for their kind assistance; and the anonymous reviewers for their detailed and constructive comments.

\section{NOTES}

1. Exceptions include Collings (1937); Harrisson and Medway (1962); Higham (1993); and Zuraina et al. (1999).

2. The terminal Pleistocene until the period immediately after the ca. 5000 B.P. Climatic Optimum (following Tjia 1996).

3. All quoted dates are uncalibrated in years B.P. unless otherwise stated.

4. Sundaland is taken to incorporate Borneo, Sumatra, Java, Bali, and perhaps Palawan, together with an expanded mainland.

5. For example, Gua Gunung Runtuh $(13,600 \pm 120$ B.P. to $2620 \pm 80$ B.P., but with most occupation dates coming between 10,000 and 7000 B.P.), and Gua Cha (occupation levels predating $6300 \pm 170$ в.P. until $810 \pm 80$ в.P.) in Malaysia; and Lang Kamnan (27,110 \pm 500 в.P. uncalibrated, through until 7168-6801 в.P. calibrated) and Spirit Cave (11,600-9400 в.P.) in Thailand.

6. There has been considerable debate on just how viable independent inland rainforest subsistence would have been (e.g., Bailey et al. 1989; Stiles 1992). However, the discovery of sites along the shores of inland lakes in peninsular Malaysia (Mokhtar 1998; Zuraina 1998) and Sabah (Bellwood 1988) suggests that, pending further details about the exact structure of the forest, parts of interior Sundaland were occupied from at least the late Pleistocene.

7. Source: Cambridge Materials Selector, Department of Engineering, University of Cambridge. With thanks to Dr. Mike Ashby.

8. The use of poison on the tips of light darts is a common feature of rainforest hunting (see, e.g., Endicott 1984; Rambo 1985; Sloan 1972).

9. Here made from a slightly curved piece of monkey fibula and constituting one of the three basic arrow types used by the Yanomamo. 


\section{REFERENCES CITED}

\section{AKerman, Kim}

1975a Baker shell implements from North West Australia. Mankind 10:16-19.

$1975 b$ The double raft or Kalwa of the West Kimberley. Mankind 10:20-23.

Allen, Harry R.

1986 Holocene mangroves and middens in Northern Australia and Southeast Asia. Bulletin of the Indo-Pacific Prehistory Association 7:1-16.

1996 The time of the mangroves: Changes in mid-Holocene estuarine environments and subsistence in Australia and Southeast Asia. Bulletin of the Indo-Pacific Prehistory Association $15: 193-205$.

Anderson, Douglas D.

1988 Excavations of a Pleistocene rockshelter in Krabi and the prehistory of southern Thailand, in Prehistoric Studies: The Stone and Metal Ages in Thailand: 43-59, ed. P. Charoenwongsa and B. Bronsen. Bangkok: Thai Antiquity Working Group, with the support of the John F. Kennedy Foundation of Thailand.

Bailey, Robert C., Genevieve Head, Mark Jenike, Bruce Owen, Robert Rechtman, and ELZBIETA ZECHENTER

1989 Hunting and gathering in tropical rain forest: Is it possible? American Anthropologist $91: 59-82$.

Barker, Graeme, Dana Badang, Huw Barton, Paul Beavitt, Michael Bird, Patrick Daly, Chris Doherty, David Gilbertson, Chris Hunt, Jessica Manser, Sue Mclaren, Victor Paz, Brian Pyatt, Tim Reynolds, Jim Rose, Garry Rushworth, and Mark Stephens

2001 The Niah Cave Project: The second (2001) season of fieldwork. Sarawak Museum Journal 56 (n.s. 77):37-103.

Barker, Graeme, Huw Barton, Michael Bird, Franca Cole, Patrick Daly, David Gilbertson, Chris Hunt, John Krigbaum, Cynthia Lampert, Helen Lewis, Lindsey Lloyd-Smith, Jessica Manser, Sue Mclaren, Francesco Menotti, Victor Paz, Phil Piper, Brian Pyatt, Ryan Rabett, Tim Reynolds, Mark Stephens, Jill Thompson, Mark Trickett, and Paula WHITTAKER

2002 The Niah Cave Project: The third (2002) season of fieldwork. Sarawak Museum Journal 57 (n.s. 78): 87-178.

Bautista, Angel P.

1999 Development of zooarchaeology for Southeast Asia. Paper presented at the International Colloqium on Archaeology in the 3rd Millennium, Penang, Malaysia.

Bellwood, Peter

1976 Archaeological research in Minahasa and the Talaud Islands, northeastern Indonesia. Asian Perspectives 19(2): 240-288.

1988 Archaeological research in the Madai-Baturong region, Sabah, in Sabah Museum Monograph Volume 2: 38-54, ed. P. Bellwood. Kota Kinabalu: Sabah Museum.

Bellwood, Peter, Goenadi Nitihaminoto, Geoffrey Irwin, Gunadi, Agus Waluyo, and Daud Tanudirjo.

1998 35,000 years of prehistory in the northern Moluccas. Modern Quaternary Research in Southeast Asia $15: 233-275$.

BlacKWOOD, BEATRICE

1950 The Technology of a Modern Stone Age People in New Guinea. Pitt-Rivers Museum Occasional Paper on Technology 3. Oxford: Oxford University Press.

BuI VINH

1991 The Da But culture in the Stone Age of Vietnam. Indo-Pacific Prehistoric Association $10: 127-131$.

Chagnon, N. A.

1992 Yanomamo, 4th ed. Case Studies in Cultural Anthropology Series. Fort Worth: Harcourt Brace Jovanovich.

Choyke, Anne M.

1997 The bone tool manufacturing continuum. Anthropozoologica 25-26:65-72.

Collings, H. D.

1937 An excavation at Bukit Chuping, Perlis. Bulletin Raffles Museum (Series B) 1(2): 94-119. 
Cranbrook, Earl of

2000 Northern Borneo environments of the past 40,000 years: Archaeozoological evidence. Sarawak Museum Journal 55 (n.s. 76) : 61-109.

DATAN, IPOI

1993 Archaeological excavations at Gua Sireh (Serian) and Lubang Angin (Gunung Mulu National Park), Sarawak, Malaysia. Special Monograph 6. Sarawak Museum Journal 65 (n.s. 66).

DAvidson, D. S.

1934 Australian spear-traits and their derivations. Journal of the Polynesian Society 43:143-162.

Dunn, Frederick L.

1964 Excavations at Gua Kechil, Pahang. Journal of the Malay Branch of the Royal Asiatic Society $37(2): 87-124$.

Dunn, Frederick L., And Daphne F. Dunn

1977 Maritime adaptations in exploitation of marine resources in Sundaic Southeast Asian prehistory. Modern Quaternary Research in Southeast Asia 3:1-28.

ENDICOTT, KIRK

1979 Batek Negrito Religion: The World-View of a Hunting and Gathering People in Peninsula Malaysia. Oxford: Clarendon Press.

1984 The economy of the Batek of Malaysia: Annual and historical perspectives. Research in Economic Anthropology 6:29-52.

ERDBRINK, D. P.

1954 Mesolithic remains of the Sampung Stage in Java: Some remarks and additions. Southwestern Journal of Anthropology $10: 294-303$.

Forestier, Hubert

1999 L'assemblage industriel de Song Keplak, Java Est: Un noveau regard sur l'utillage lithique et de l'homme moderne au début de l'Holocene en Indonésie. Bulletin de L'Ecole Française D'Extrême Orient 86:129-159.

Griffin, P. B.

1997 Technology and variation in arrow design among the Agta of northeastern Luzon, in Projectile Technology: 267-286, ed. H. Knecht. New York: Plenum Press.

Grindod, John, Patrick Moss, and Sander van der Saars

2002 Late Quaternary mangrove pollen records from continental and ocean cores in the north Australasian region, in Bridging Wallace's Line: The Environmental and Cultural History and Dynamics of the SE Asian-Australasian Region: 119-46, ed. A. P. Kershaw, B. David, N. Tapper, D. Penny, and J. Brown. Advances in Geoecology 34. Reiskirchen: Catena Verlag.

Ha VAN TAN

1999 Prehistoric Archaeological Research in Vietnam Today. Paper presented at The International Colloquium on Archaeology in Southeast Asia in the $3^{\text {rd }}$ Millennium, Penang, Malaysia.

HAILE, N. S.

1971 Quaternary shorelines in West Malaysia and adjacent parts of the Sunda Shelf. Quaternaria $15: 333-343$.

HAMES, R. B.

1979 A comparison of the efficiencies of the shotgun and the bow in neotropical forest hunting. Human Ecology 7(3): 219-252.

HARrison, TERRY

1998 Vertebrate faunal remains from Madai Caves (MAD 1/28), Sabah, East Malaysia, in IndoPacific Prehistory Association Bulletin 17:85-92.

HARrisson, TOM

1966 Lobang Angus, a frequentation cave at Niah-I. Sarawak Museum Journal 14 (n.s. 2829): $217-223$.

1967 Niah Caves: progress report to 1967. Sarawak Museum Journal 15 (n.s. 30-31) : 95-97.

Harrisson, Tom, and Lord Medway

1962 A first classification of prehistoric bone and tooth artifacts (based on material from Niah Great Cave). Sarawak Museum Journal 10 (n.s. 19-20) :335-362. 
Higham, Charles F. W.

1989 The Archaeology of Mainland Southeast Asia. Cambridge World Archaeology. Cambridge: Cambridge University Press.

1993 The bone, antler and turtle carapace technology, in The Excavation of Khok Phanom Di: A Prehistoric Site in Central Thailand: Vol. III: The Material Culture Part 1: 1-44, ed. C.F.W. Higham and R. Thosarat. London: Society of Antiquaries and Thames and Hudson.

Higham, Charles F. W., and Rachanie Bannanurag

1990 The Excavation of Khok Phanom Di: A Prehistoric Site in Central Thailand: Vol. 1. The Excavation Chronology and Human Burials. London: Society of Antiquaries and Thames and Hudson.

Higham, Charles F. W., R. Ewan Fordyce, and Dougald J. W. O'Reilly

1998 The faunal remains and worked bone, in The Excavation of Nong Nor: A Prehistoric Site in Central Thailand: 119-126, ed. C.F.W. Higham and R. Thosarat. Oxford: Oxbow Books.

Higham, Charles F. W., and Amphan Kijngam

1984 Prehistoric Investigations in Northwestern Thailand, Part 1. International Series 231(i). Oxford: British Archaeological Reports.

Higham, Charles F. W., and Bernard Maloney

1989 Coastal adaptation, sedentism, and domestication: a model for socio-economic intensification in prehistoric Southeast Asia, in Foraging and Farming: The evolution of plant exploitation: 650-666, ed. D. R. Harris and G. C. Hillman. London: Unwin Hyman.

Higham, Charles F. W., and Rachanie Thosarat

1998 Prehistoric Thailand. London: Thames and Hudson.

Johnson, Eileen, Gustavo Politis, and Maria Gutierrez

2000 Early Holocene bone technology at the La Olla 1 site, Atlantic coast of the Argentine Pampas. Journal of Archaeological Science 27:463-477.

JONES, RHYS

1989 East of Wallace's Line: Issues and problems in the colonization of the Australian continent, in The Human Revolution: 743-782, ed. P. Mellars and C. Stringer. Edinburgh: Edinburgh University Press.

Kohl, G., AND Hans QuitTa

1978 Berlin radiocarbon dates V. Radiocarbon 20(3):392.

LAMPERT, R. J.

1966 An excavation at Durras North, New South Wales. Archaeology and Physical Anthropology in Oceania 1(2): 83-118.

Love, J.R.B.

1939 The double-raft of northwestern Australia. Man 150:158-160.

Matthews, J. M.

1966 A review of the 'Hoabinhian' in Indo-China. Asian Perspectives 11:86-95.

MCKInNon, E. Edwards

1991 The Hoabinhian in the Wampu/Lau Biang valley of northeastern Sumatra: An update. Indo-Pacific Prehistory Association Bulletin 10:132-142.

Medway, Lord

1966 Animal remains from Lobang Angus, Niah. Sarawak Museum Journal 14 (n.s. 28-29) : 185216.

MEEHAN, BARBARA

1982 Shell Bed to Shell Midden. Canberra: Australian Institute of Aboriginal Studies.

MOKHTAR SAIDIN

1998 Ten years with the Centre of Archaeological Research Malaysia. Paper presented at the Indo-Pacific Prehistory Association Conference, Melaka, Malaysia.

Mulvaney, John, and Joe Kamminga

1999 Prehistory of Australia. Washington, DC: Smithsonian Institute Press.

Nishimura, Masanari, and Nguyen Kim Dung

2002 Excavation of An Son: A Neolithic mound site in the middle reach of the Vam Co Dong river, Southern Vietnam. Bulletin of the Indo-Pacific Prehistory Association 22:101-109. 
Olsen, Sandra L., and Ian C. Glover

2004 The bone industry of Ulu Leang 1 and Leang Burung 1 rockshelters, Sulawesi, Indonesia in its regional context, in Proceedings of the Second International Conference of the Association of Southeast Asian Archaeologists in Western Europe, ed. S. Keates and M. Santoni. Modern Quaternary Research in Southeast Asia. Rotterdam: Balkema.

Oswalt, W. H.

1976 An Anthropological Analysis of Food-Getting Technology. New York: John Wiley and Sons.

Pawlik, Alfred F.

n.d. Arubian, Acheulean, or Acheulean-like? Early Palaeolithic in Central Luzon, Philippines. Unpublished manuscript.

Pham Huy Thong, Hoang Xuán Chinh, and Nguyên Khán Su

1990 Hang Con Moong. Hanoi: Xuat ban.

PoKines, J., AND M. KRUPA

1997 Self-barbed antler spearpoints and evidence of fishing in the late Upper Palaeolithic of Cantabrian Spain, in Projectile Technology: 241-262, ed. H. Knecht. New York: Plenum Press.

\section{PoOKajorn, Surin}

1996 Human activities and environmental changes during the late Pleistocene to middle Holocene in South Thailand and Southeast Asia, in Humans at the End of the Ice Age: The Archaeology of the Pleistocene-Holocene Transition: 201-213, ed. L. G. Straus, B. V. Erikson, and J. M. Erlandson. New York: Plenum Press.

Pookajorn, Surin, S. Sinsakul, Y. Chaimanee, A. Ukrit, P. Eiamsiri, B. na Songkhla, A. Thongpakdee, W. Pongmala, W. Chuakul, S. Thongpraditchoti, N. Opaskiatikul, P. Chaiard, and C. Pinnoi

1996 Final Report of Excavations at Moh Khiew Cave, Krabi Province; Sakai Cave, Trang Province; and Ethnoarchaeological Research of Hunter-Gatherer Group, Socall Mani, or Sakai, or Orang Asli at Trang Province: The Hoabinhian Research Project in Thailand, vol. 2. Bangkok: Silpakorn University, Faculty of Archaeology.

RABETT, RyAN J.

2002 Bone Technology and Subsistence Variability in Prehistoric Southeast Asia. Ph.D. diss. University of Cambridge, Cambridge.

2004 The ones that come ready made: The identification and use of Sus tusks as tools at prehistoric cave sites in Malaysia. Archaeofauna.

RAMBO, TERRY

1985 Primitive polluters: Semang impact on the Malaysian tropical rain forest ecosystem. Anthropological Papers Museum of Anthropology University of Michigan 76:29-104.

Reynolds, Timothy E. G.

1990 The Hoabinhian: A review, in Bibliographic Review of Far Eastern Archaeology, 1-30, ed. G. L. Barnes. Oxford: Oxbow Books.

1992 Excavations at Banyan Valley Cave, Northern Thailand: A report on the 1972 season. Asian Perspectives 31:77-97.

RÖNNBÄCK, PATRIK

1999 The ecological basis for economic value of seafood production supported by mangrove ecosystems. Ecological Economics 29:235-252.

Roth, W. E.

1908 Australian canoes and rafts. Man 88-89:161-162.

SARASIN, F.

1933 Prehistoric research in Siam. Journal of the Siam Society 26(2):171-202.

Scheinsohn, Vivian G.

1997 Use-wear patterns on bark removers, in Proceedings of the 1993 Bone Modification Conference, Hot Springs, South Dakota: 265-276, ed. L. A. Hannus, L. Rossum, and R. P. Winham. Occasional Publication 1. Sioux Falls, SD: Augustana College, Archeology Laboratory.

\section{Scheinsohn, Vivian, and José Luis Ferretti}

1995 The mechanical properties of bone materials in relation to the design and function of prehistoric tools from Tierra Del Fuego, Argentina. Journal of Archaeological Science 22:711717. 
Semenov, S. A.

1964 Prehistoric Technology: An Experimental Study of the Oldest Tools and Artifacts from Traces of [1957] Manufacturing and Wear, trans. M. W. Thompson. London: Cory, Adams and Mackay Ltd.

ShOocongdeJ, Rasmi

1996 Forager Mobility Organization in Seasonal Tropical Environments: A View from Lang Kamnan Cave, Western Thailand. Ph.D. diss. University of Michigan, Ann Arbor.

Sievering, Gale De G.

1962 The prehistoric cemetary at Bukit Tengku Lembu, Perlis. Federation Museums Journal $7: 25-55$.

Sillitoe, Paul

1988 Made in Niugini: Technology in the Highlands of Papua New Guinea. London: British Museums Publications, in association with the University of Durham Publications Board.

SLOAN, C.

1972 Punan hunting methods. Sarawak Museum Journal 20 (n.s. 40-41):262-269.

Sørensen, Per

1988 Archaeological Excavations in Thailand: Surface Finds and Minor Excavations (Discussion and Conclusion). London: Curzon.

1999 The Ban Kao culture of Thailand and Malaysia: Its origin, the present geographical extension, its chronology, and relative chronological subphases. Paper presented at the International Colloquium on Archaeology in Southeast Asia in the 3rd Millennium, Penang, Malaysia.

Sørensen, Per, and T. Hatting

1966 Archaeological Excavations in Thailand Vol. II Ban Kao; Thai-Danish Prehistoric Expedition 1960-62. Copenhagen: Munksgaard.

STeinbring, J.

1966 The manufacture and use of bone de-flensing tools. American Antiquity 31(4):571-581.

STILES, DANiel

1992 The hunter-gatherer "revisionist" debate. Anthropology Today 8(2):13-17.

Storm, P.

1995 The Evolutionary Significance of the Wajak Skulls. Scripta Geologica 110. Leiden: Nationaal Natuurhistorisch Museum.

\section{STRATHERn, MARILYN}

1969 Stone axes and flake tools: Evaluations from two New Guinea Highlands Societies. Proceedings of the Prehistoric Society 13:311-329.

Thiel, Barbara

1990 Excavations at Musang Cave, northeast Luzon, Philippines. Asian Perspectives 28(1):6181.

Thomson, D. F.

1936 Notes on some bone and stone implements from North Queensland. Miscellaneous Papers Journal of the Royal Anthropological Institute 66:71-81.

TJIA, Hong DJIN

1996 Sea-level changes in the tectonically stable Malay peninsula. Quaternary International 31:95-101.

Tweedie, Michael W. F.

1940 The excavation of Gua Madu. Journal of the Malay Branch of the Royal Asiatic Society 26(2): 1-90.

1953 The Stone Age in Malaya. Journal of the Malay Branch of the Royal Asiatic Society 26(2):1-90.

VAN Es, L.J.C.

1929 The prehistoric remains in the Sampoeng cave, Residency of Ponorogo, Java, in Proceedings of the 4th Pacific Science Congress, Java 3:329-340.

Van Heekeren, H. R.

1972 The Stone Age of Indonesia. The Hague: Nijhof.

Van Heekeren, H. R., and C. E. Knuth

1967 Archaeological Excavations in Thailand Vol. I: Sai Yok, Stone-Age Settlements in the Kanchanaburi Province. Copenhagen: Munksgaard. 
White, Carmel, and Nicolas Peterson

1969 Ethnographic interpretations of the prehistory of western Arnhem Land. Southwestern Journal of Anthropology $25: 45-67$.

Woodroffe, Colin D., John Chappell, and Bruce G. Thom

1988 Shell middens in the context of estuarine development: South Alligator River, Northern Territory. Archaeology in Oceania 23:95-103.

\title{
Zolkuranian Hasan
}

1989 Gua Harimau: Satu Laporan Awal. Jurnal Persatuan Muzium Malaysia (PURBA) 8:41-52. (In Malay.)

Zuraina Majid

1998 Radiocarbon dates and the cultural sequence in the Lenggong Valley and beyond, in $A r$ chaeological Research and Museums in Malaysia: 241-249, ed. Zuraina Majid. Kuala Lumpur: Department of Museums and Antiquities Malaysia.

Zuraina Majid, Jeffrie Ignatius, Tjia, Hong Djin, and Peter Koon

1999 Some interesting late Pleistocene-early Holocene finds from excavations in Balambangan Island, Sabah, Malaysia. Unpublished manuscript.

\begin{abstract}
This paper focuses on the contribution that the study of bone technology is making to the understanding of early tropical subsistence in Southeast Asia. Newly completed research suggests that during the period from the terminal Pleistocene to mid Holocene, bone tools may have featured prominently in coastal subsistence. There are indications that this technology may have had a particular association with hunting and gathering in the mangrove forests that proliferated along many coasts during this period. The study of these tools thus represents a rare chance to examine prehistoric extractive technologies, which are generally agreed to have been predominantly made on organic, nonpreserving media. The evidence presented also suggests that prehistoric foragers from this region possessed a good working understanding of the mechanical properties of bone and used bone implements where conditions and needs suited the parameters of this material. KeYwords: bone technology, Sundaland, coastal subsistence.
\end{abstract}

